\title{
ADHERENCE ASSAYS AND SLIME PRODUCTION OF VIBRIO ALGINOLYTICUS AND VIBRIO PARAHAEMOLYTICUS
}

\author{
Fethi Ben Abdallah ${ }^{1,2 *}$; Kamel Chaieb ${ }^{1}$; Tarek Zmantar¹; Hela Kallel²; Amina Bakhrouf ${ }^{1}$ \\ ${ }^{1}$ Laboratoire d'Analyse, Traitement et Valorisation des Polluants de l'Environnement et des Produits. Faculté de Pharmacie \\ Rue Avicenne. Monastir 5000, Tunisia; ${ }^{2}$ Unité de fermentation et de développement de vaccins virologiques. Institut Pasteur de \\ Tunis.13 place Pasteur. 1002. Tunisia.
}

Submitted: June 04, 2008; Returned to authors for corrections: August 16, 2008; Approved: March 31, 2009.

\begin{abstract}
In this study we investigated the phenotypic slime production of Vibrio alginolyticus and Vibrio parahaemolyticus strains, food-borne pathogens, using a Congo red agar plate assay. Furthermore, we studied their ability to adhere to abiotic surfaces and Vero cells line. Our results showed that only $V$. alginolyticus ATCC 17749 was a slime-producer developing almost black colonies on Congo red agar plate. Adherence to glace tube showed that all V. alginolyticus strains were more adherent than V. parahaemolyticus. Only V. alginolyticus ATCC 17749 was found to be able to form biofilm on polystyrene microplate wells $\left(\mathrm{OD}_{570}\right.$ $=0.532$ ). Adherence to Vero cells showed that all tested strains were non adherent after $30 \mathrm{~min}$, however after $60 \mathrm{~min}$ all the studied strains become adherent. The percentage of adherence ranged from $1.23 \%$ to $4.66 \%$.
\end{abstract}

Key words: Vibrio, slime production, adherence, abiotic surface, Vero cells

\section{INTRODUCTION}

Bacterial biofilms are complex communities of microorganisms embedded in a self-produced matrix and adhering to inert or living surfaces (7). Biofilms have been observed on a variety of surfaces and were considered to be the prevailing microbial lifestyle in most environments (26). The formation of biofilms on food and food-processing surfaces, and in water distribution systems, constitutes an increased risk for product contamination with spoilage or pathogenic microflora (9). The development of biofilms can be seen as a five-stage process (24): (i) initial reversible adsorption of cells to the solid surface, (ii) production of extracellular polymeric matrix substances resulting in an irreversible attachment, (iii) early development of biofilm architecture, (iv) maturation, and (v) dispersion of single cells from the biofilm.

Biofilm formation on abiotic surfaces is extensively examined and represents very important issues in food sanitation. It has been shown that bacterial cells trapped in the biofilm matrix created by the exopolysaccharide glycocalyx are more resistant to sanitizers and other environmental stresses than free cells (29). Pathogenic bacteria released from the biofilm definitely lead to food hygiene problems (8).

Biofilm formation of marine vibrios has been reported elsewhere for V. alginolyticus (14), V. cholerae (12), V. harveyi (13). Lopez-Cortes et al. (15) reported the adhesion property of pathogenic vibrios to seafood. Comprehensive examination of the adherence of pathogenic vibrios to biotic surfaces could elucidate the pathogenesis of these bacteria in the host.

The aim of this study was to investigate the slime production and the ability of Vibrio alginolyticus and Vibrio parahaemolyticus strains to adhere to polystyrene microplate, glass tube and Vero cells line.

\section{MATERIALS AND METHODS}

\section{Bacterial strains}

Nine Vibrio strains were used in this study including two $\mathrm{V}$. alginolyticus strains ( $\mathrm{S} 3$ and $\mathrm{S} 4$ ) isolated respectively from the internal organs of aquacultured diseased gilthead sea bream

*Corresponding Author. Mailing address: Laboratoire d'Analyse, Traitement et Valorisation des Polluants de l'Environnement et des Produits. Faculté de Pharmacie Rue Avicenne. Monastir 5000, Tunisie. Tel.: + 21673466 244; Fax: + 21673461830 . E-mail: fetyben@yahoo.fr 
(Sparus aurata) and sea bass (Dicentrarchus labrax) according to method previously described by Ben Kahla et al. (2) and three $V$. alginolyticus strains designed respectively S5, S6, and S7, isolated from Tunisian seawater were also used. All the isolated strains were identified biochemically using Api 20NE system (Bio-Merieux).

In addition, $V$. parahaemolyticus strain isolated from the Calich estuary (Alghero, Italy), and three reference strains: Vibrio alginolyticus ATCC 33787, V. alginolyticus ATCC 17749 and $V$. parahaemolyticus ATCC 17802 were included in this study (Table 1). All these strains were provided gratefully by Professor S. Zanetti (Dipartimento di Scienze Biomediche, Sezione di Microbiologia Sperimentale e Clinica, Universita ' degli studi di Sassari, Sassari, Italy).

\section{Phenotypic characterization of slime-producing bacteria}

Qualitative detection of biofilm formation was studied by culturing the strains on Congo red agar (CRA) plates as described previously (10). Vibrio strains were inoculated into the surface of CRA plates, prepared by mixing $0.8 \mathrm{~g}$ Congo red with $36 \mathrm{~g}$ saccharose (Sigma) in $1 \mathrm{~L}$ of brain heart infusion agar, and were incubated for $24 \mathrm{~h}$ at $30^{\circ} \mathrm{C}$ under aerobic conditions and followed overnight at room temperature (4) Slime producing bacteria appeared as black colonies, whereas non-slime producers remained non pigmented (25).

\section{Biofilm formation assays by Vibrio strains Biofilm formation in glass test tubes}

For the biofilm formation assay, each Vibrio strain, was cultured in SWT medium containing (per liter): $5 \mathrm{~g}$ of BactoTryptone (Difco), $3 \mathrm{~g}$ of yeast extract (Difco), $3 \mathrm{ml}$ of glycerol, $700 \mathrm{ml}$ of filtered seawater, and $300 \mathrm{ml}$ of distilled water, at $28^{\circ} \mathrm{C}$ with shaking and then transferred to glass test tubes. The cells were incubated without shaking for $10 \mathrm{~h}$ at $28^{\circ} \mathrm{C}$, then stained with $1 \%$ crystal violet solution to visualise cells attached to the test tube (28). After incubation for $15 \mathrm{~min}$, the tubes were rinsed with sterile distilled water. Biofilms formed at the air liquid interface were stained purple. All the strains were tested in triplicate.

\section{Quantitative adherence assay}

Biofilm production by Vibrio strains was determined using a semi-quantitative adherence assay on 96-well tissue culture plates, as described previously (4). Strains were grown in Trypticase Soy broth supplemented with $1 \%$ (w/v) $\mathrm{NaCl}$ (TSB $1 \%$, Pronadisa, Spain), Following overnight incubation at $30^{\circ} \mathrm{C}$, the optical density at $600 \mathrm{~nm}\left(\mathrm{OD}_{600}\right)$ of the bacteria was measured. An overnight culture, grown in TSB $1 \%$ at $30^{\circ} \mathrm{C}$, was diluted to 1:100 in TSB supplement with $2 \%(w / v)$ glucose. A total of $200 \mu \mathrm{l}$ of cell suspensions was transferred in a Ubottomed 96-well microtiter plate (Nunc, Roskilde, Denmark). Each strain was tested in triplicate. Wells with sterile TSB alone were served as controls. The plates were incubated aerobically at $30^{\circ} \mathrm{C}$ for $24 \mathrm{~h}$. The cultures were removed and the microtiter wells were washed twice with phosphate-buffered saline $(7 \mathrm{mM}$ $\mathrm{Na}_{2} \mathrm{HPO}_{4}, 3 \mathrm{mM} \mathrm{NaH}_{2} \mathrm{PO}_{4}$ and $130 \mathrm{mM} \mathrm{NaCl}$ at $\mathrm{pH}$ 7.4) to remove non-adherent cells and dried in an inverted position. Adherent bacteria were fixed with $95 \%$ ethanol and stained with $100 \mu \mathrm{l}$ of $1 \%$ crystal violet (Merck, France) for $5 \mathrm{~min}$. The excess stain was rinsed and poured off and the wells were washed three times with $300 \mu \mathrm{l}$ of sterile distilled water. The water was then cleared and the microplates were air-dried. The optical density of each well was measured at $570 \mathrm{~nm}\left(\mathrm{OD}_{570}\right)$ using an automated Multiskan reader (GIO. DE VITA E C, Rome, Italy). Biofilm formation was interpreted as highly positive $\left(\mathrm{OD}_{570} \geq 1\right)$, lowgrade positive $\left(0.1 \leq \mathrm{OD}_{570}<1\right)$, or negative $\left(\mathrm{OD}_{570}<0.1\right)$.

\section{Vero cells adherence assays}

Quantitative adherence assays was performed with kidney epithelial cells of the African Green Monkey (Vero) as described by Chatti et al. (6). Vero cells were seeded at a concentration of $2 \times 10^{5}$ and grown overnight in minimal essential medium (MEM) with Earle's salts and $10 \%$ fetal bovine serum in 96 -well microtiter plates at $37^{\circ} \mathrm{C}$ with $5 \% \mathrm{CO}_{2}$. Each Vibrio strain was grown overnight in brain heart infusion with $0.5 \% \mathrm{NaCl}$ at $30^{\circ} \mathrm{C}$ with shaking. The bacterial cells were washed three times by centrifugation at $6000 \times \mathrm{g}$ for $15 \mathrm{~min}$ with MEM without serum and resuspended in the same medium. The number of bacteria in the suspension was adjusted to $10^{7} \mathrm{CFU} / \mathrm{ml}$. The monolayers of Vero cells were inoculated with $10^{7} \mathrm{CFU} / \mathrm{ml}$ for each tested strain, and incubated at $37^{\circ} \mathrm{C}$ in $5 \% \mathrm{CO}_{2}$ for $30 \mathrm{~min}$ and $60 \mathrm{~min}$. Then, bacterial suspension was removed to exclude the unattached bacteria. The monolayers of Vero cells were washed 3 times with DMEM, and $1 \mathrm{ml}$ Triton X-100 in PBS was added for $5 \mathrm{~min}$ at room temperature to release the bacteria from the cells. The number of bacteria was estimated by plating serial dilutions. All experiments were performed in triplicate.

\section{Statistical analysis}

Each analysis was performed using the S.P.S.S. 13.0 statistics package for Windows. The differences in the degree of biofilm formation (semi-quantitative adherence assay on 96-well tissue culture plates) and adherence potency to Vero cells were examined by the Friedman test, followed by the Wilcoxon signed ranks test. $P$-values of $<0.05$ were considered as significant. Other analysis were realised between the origin of strains, slime production and glass test tube adherence.

\section{RESULTS}

\section{Determination of slime production}

Phenotypic slime production was assessed by culturing the investigated strains on CRA plates. Among the 9 Vibrio strains tested in this study, only V. alginolyticus ATCC 17749 (S2) was 
a slime-producer developing almost black colonies whereas the remaining 8 strains are considered as non-producers since they showed white colonies on CRA plates (Fig. 1)

\section{Biofilm formation in glass test tubes}

The results of adherence assay to test glace tube showed that $V$. alginolyticus strains were more adherent than $V$. parahaemolyticus which is slightly adherent (Fig. 2). Among the seven $V$. alginolyticus strains, we have observed the existence of three different phenotypes (Fig. 2). In addition, the strains S3 and S7 isolated respectively from diseased Dicentrarchus labrax and seawater were very adherent (Fig. 2 a). Furthermore, V. alginolyticus ATCC 33787 (S1) was adherent (Fig. 2b). Whereas, the strain S4 isolated from diseased Sparus aurata, the strains S5 and S6 isolated from seawater and V. alginolyticus ATCC 17749 were fairly adherent (Fig. 2c).

\section{Quantitative Biofilm formation}

All 9 Vibrio strains were screened for their adherence to polystyrene microplate plates. The results showed that only $\mathrm{V}$. alginolyticus ATTC 17749 is able to form biofilm $\left(\mathrm{OD}_{570}=0,532\right)$ and was considered as low-grade positive, whereas all the other tested strains did not show any biofilm formation (Table 1).

\section{Vero cells adherence}

Quantitative adherence of $V$. alginolyticus and $V$. parahaemolyticus to Vero cells was assessed in two times: after 30 min of contact we have noted that all strains were non adherent, whereas after 60 min of contact we have noted that all strains were adherent but with different percentages. The adherence is ranged from $1.23 \%$ to $4.66 \%$. Our results showed
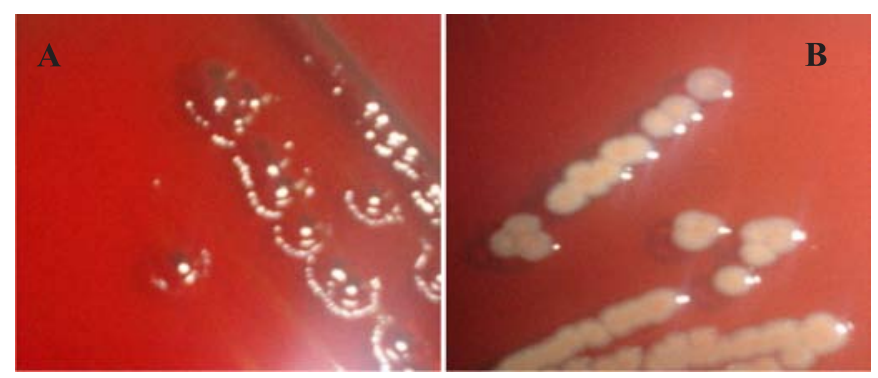

Figure 1. Colourimetric scale for colony analysis of slime production by V. alginolyticus and V. parahaemolyticus using Congo Red agar assay (G8x). A: slime producing strain (almost black); B: non-producing strain (white).

that after $1 \mathrm{~h}$ of contact, the two V. alginolyticus reference strains (S1 and S2) were more adherent than the other tested strains (Table 1).

Statistical analysis revealed a significant difference between the $\mathrm{OD}_{570}$ and adherence to Vero cells $(P<0.05)$. However, the statical analysis between the origin of strains and slime production, the origin of strains and test tube adherence showed a not significant difference ( $P=0.342$ and 0.304 respectively).

\section{DISCUSSION}

The results, developed in this study, showed that Vibrio, food-borne pathogen, is able to produce biofilm on abiotic surface as well as cells. Our results showed that only $V$. alginolyticus ATCC 17749 was categorized as slime-producer

Table 1. Slime production and adherence to polystyrene microplate and to Vero cells of Vibrio strains studied.

\begin{tabular}{|c|c|c|c|c|c|c|c|}
\hline \multirow[t]{2}{*}{ Strains } & \multirow[t]{2}{*}{ Biotype } & \multirow[t]{2}{*}{ Sample } & \multirow[t]{2}{*}{$\begin{array}{c}\text { Phenotype } \\
\text { of strains (CRA) }\end{array}$} & \multirow[t]{2}{*}{$\begin{array}{l}\text { Production } \\
\text { of slime }\end{array}$} & \multirow[t]{2}{*}{$\mathrm{OD}_{570} \pm \mathrm{SD}$} & \multicolumn{2}{|c|}{$\begin{array}{c}\text { Vero cells } \\
\text { adherence }(\%) \pm \mathrm{SD}\end{array}$} \\
\hline & & & & & & $30 \mathrm{~min}$ & $60 \mathrm{~min}$ \\
\hline $\mathrm{S} 1: V$. alginolyticus & 7454744 & ATCC 33787 & White & Non producer & $0.040 \pm 0.038$ & 0 & $4.66 \pm 0.577$ \\
\hline $\mathrm{S} 2:$ V. alginolyticus & 7454744 & ATCC 17749 & Almost black & Producer & $0.532 \pm 0.013$ & 0 & $4.33 \pm 0.577$ \\
\hline $\mathrm{S} 3:$ V. alginolyticus & 7754444 & diseased & & & & & \\
\hline $\mathrm{S} 4:$ V. alginolyticus & 7456744 & $\begin{array}{c}\text { Dicentrarchus } \\
\text { labrax } \\
\text { diseased }\end{array}$ & White & Non producer & $0.024 \pm 0.008$ & 0 & $3.33 \pm 0.577$ \\
\hline & & Sparus aurata & White & Non producer & $0.018 \pm 0.004$ & 0 & $2.53 \pm 0.251$ \\
\hline $\mathrm{S} 5: V$. alginolyticus & 7435544 & seawater & White & Non producer & $0.016 \pm 0.005$ & 0 & $1.36 \pm 0.152$ \\
\hline $\mathrm{S} 6:$ V. alginolyticus & 7454744 & seawater & White & Non producer & $0.056 \pm 0.013$ & 0 & $1.23 \pm 0.057$ \\
\hline $\mathrm{S} 7:$ V. alginolyticus & 7434644 & seawater & White & Non producer & $0.012 \pm 0.003$ & 0 & $2.13 \pm 0.305$ \\
\hline $\mathrm{S} 8:$ V. parahaemolyticus & 7076744 & ATCC 17802 & White & Non producer & $0.019 \pm 0.005$ & 0 & $2.23 \pm 0.602$ \\
\hline S9: V. parahaemolyticus & 7277644 & seawater & White & Non producer & $0.067 \pm 0.013$ & 0 & $2.06 \pm 0.635$ \\
\hline
\end{tabular}




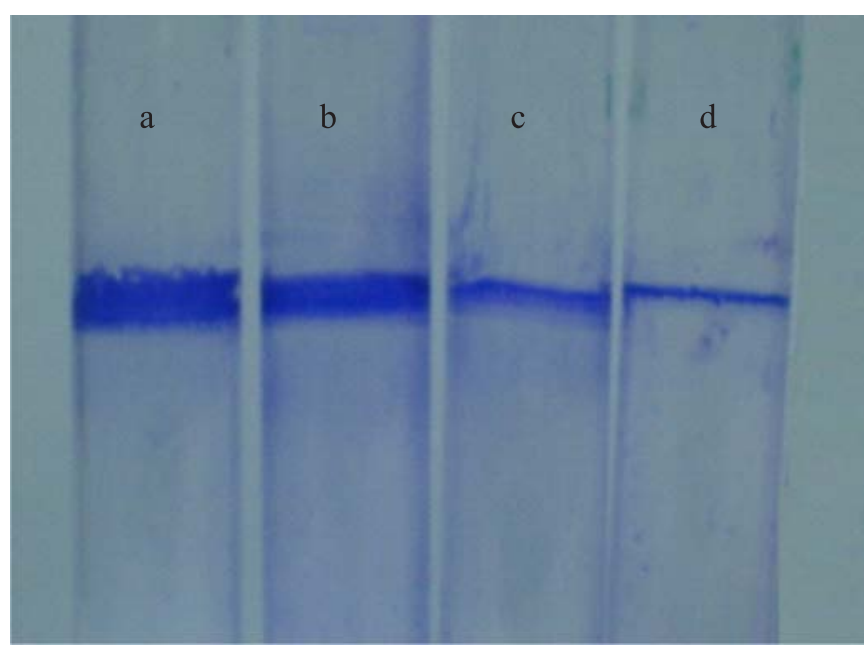

Figure 2. Adherence of Vibrio tested strains to test glace tube: a (S3 and S7): very adherent strains; b (S1): adherent strain; c (S2, S4, S5 and S6) fairly adherent strains; d: slightly adherent strains (S8 and S9).

on CRA plate, developing almost black colonies. Indeed, slime production play an important role in the pathogenesis of infections caused by different micro-organismes (1), and is considered to be a significant virulence factor for some staphylococci (16) as well as for Aeromonas spp which indicates the high-risk source contamination (23). Slimes are generally polysaccharidic materials, although other polymers may also be present. They are probably involved in the protection of microbial cells. In addition microorganisms which produce these exopolymers, such as Vibrio, are more resistant to desiccation, predation and toxic chemicals (20). However, these molecules are also important in the formation of biofilms on surfaces. Indeed, exopolymers have been considered to be involved in the first steps of biofilm formation (19). Pringent-Combaret et al. (22) found that the E. coli exopolysaccharide colanic acid was involved only in the ability of the cells to produce voluminous biofilm, and not in the adherence of the cells to plastic surfaces, while Gaylarde and Beech (11) demonstrated that lipopolysaccharides of the outer membrane of Pseudomonas spp. and sulphate-reducing bacteria were the important molecules in initial adhesion to a metal surface.

Qualitative adherence of tested Vibrio strains performed on glace test tube showed that $V$. alginolyticus was very adherent contrary to V. parahaemolyticus. According to Wolfe et al. (28), this difference may be due to the presence and the expression of rpoN gene especially in $V$. alginolyticus.

Quantitative adherence to polystyrene microplate plates showed that among the 9 tested strains, only $V$. alginolyticus ATCC 17749 was capable to form biofilm. Indeed, biofilm formation begins with the attachment of bacteria to abiotic surface, by means of pili, flagella or other materials, followed by the production of exopolysaccharides to form a glycocalyx (29). The attachment of bacteria, such as Vibrio, to glace, polystyrene or other surfaces is affected by various physicochemical and biological factors including bacterial surface hydrophobicity (27), surface appendages, extracellular polymeric substances (5), bacterial physiological state, electrolyte concentration in the medium (17) surface charge and swimming speed. Kogure et al. (14) reported that the attachment of V. alginolyticus to glass surfaces is dependent on swimming speed.

Adherence of pathogenic bacteria, such as Vibrio, to host cells or tissues is a key step in virulence (31). In the present study, culture cells adherence assay performed with kidney epithelial cells of the African Green Monkey, showed the ability of two Vibrio species to adhere, first step, to invasion. Our results may explain the existence of some Vibrio species especially $V$. alginolyticus, in the internal organs of moribund cultured Sparus aurata and Dicentrarchus labrax (2). According to Wong et al. (29) the two V. alginolyticus reference strains S1 and S2 are considered more pathogens than other tested strains since have the highest adherence percentage: $4.66 \%$ for S1 and $4.33 \%$ for S2. Attachment to culture cells has been studied in some Vibrio species especially with Human epithelial cells (21), Human intestinal cells (30), and HeLa cells (18). Indeed, the adherence of pathogens to host surfaces is a prerequisite step in the pathogenesis of almost all infectious diseases. Bacterial adherence requires the specific interaction of bacterial molecules, termed adhesins with host cell membrane molecules or extracellular matrix proteins (3).

In conclusion, $V$. alginolyticus and $V$. parahaemolyticus, ubiquitous germs are able to adhere to abiotic and biotic surfaces. However, these two pathogens did not show a good ability to form biofilm in the polystyrene microplate contrary to glace tube and culture cells.

\section{ACKNOWLEDGMENTS}

We are grateful to Pr. Mahjoub Ouni (Laboratoire des Maladies Transmissibles et Substances Biologiquement Actives, Faculté de Pharmacie de Monastir- Tunisia) for his support in cell culture experiments.

\section{RESUMO}

\section{Ensaios de adesão e produção de muco por Vibrio alginolyticus e Vibrio parahaemolyticus}

Neste estudo, investigou-se a produção de muco por cepas de Vibrio alginolyticus e Vibrio parahaemolyticus através do teste em placa de ágar com vermelho congo. Estudou-se também a capacidade de adesão à superfícies abióticas e células Vero. 
Os resultados indicaram que somente $V$. alginolyticus ATCC 17749 produziu muco, formando colônias quase negras nas placas de ágar com vermelho congo. O teste de adesão a tubos de vidro indicou que as cepas de V. alginolyticus foram mais aderentes do que as de V. parahaemolyticus. Somente V. alginolyticus ATCC 17749 foi capaz de formar biofilme nos poços das microplacas de poliestireno $\left(\mathrm{OD}_{570}=0,532\right)$. Testes de adesão a células Vero mostraram que nenhuma das cepas apresentou adesão em $30 \mathrm{~min}$, mas todas aderiram após $60 \mathrm{~min}$. A porcentagem de adesão variou de 1,23\% a 4,66\%.

Palavras-chave: Vibrio, produção de muco, adesão, superfície abiótica, células Vero

\section{REFERENCES}

1. Alcaráz, L.E.; Satorres, S.E.; Lucero, R.M.; Puig de centorli O.N. (2003). Species identification, slime production and oxacillin susceptibility in coagulase-negative staphylococci isolated from nosocomial specimens. Braz. J. Microbiol. 34 (1), 45-51.

2. Ben Kahla, N.A.; Chaieb, K. ; Besbes, A. ; Zmantar, T. ; Bakhrouf, A. (2006). Virulence and enterobacterial repetitive intergenic consensus PCR of Vibrio alginolyticus strains isolated from Tunisian cultured gilthead sea bream and sea bass outbreaks. Vet. Microbiol. 117 (2-4), 321-327.

3. Brown, N.F.; Boddey, J.A.; Flegg, C.P.; Beacham, I.R. (2002). Adherence of Burkholderia pseudomallei Cells to cultured human epithelial cell lines is regulated by growth temperature. Infect. Immun. 70 (2), 974-980.

4. Chaieb, K.; Chehab, O.; Zmantar, T.; Rouabhia, M.; Mahdouani, K.; Bakhrouf, A. (2007). In vitro effect of $\mathrm{pH}$ and ethanol on biofilm formation by clinical ica-positive Staphylococcus epidermidis strains. Ann. Microbiol. 57 (3), 431-437.

5. Characklis, W.G. (1990). Biofilm processes. In W. G. Characklis and K. C. Marshall (ed.), Biofilms. John Wiley \& Sons, New York, N.Y. p. $195-231$.

6. Chatti, A.; Daghfous, D.; Landoulsi, A. (2007). Effect of seqA mutation on Salmonella Typhimurium virulence. J. Infection. 54 (6), 241-245.

7. Costerton, J.W.; Stewart, P.S.; Greenberg, E.P. (1999). Bacterial biofilms: a common cause of persistent infections. Science. 284 (5418), 1318-1322.

8. Dewanti, R.; Wong, A.C.L. (1995). Infuence of culture conditions on biofilm formation by Escherichia coli O157:H7. Int. J. Food. Microbiol. 26 (2), 147-164.

9. Donlan, R.M. (2002). Biofilms: microbial life on surfaces. Emerg. Infect. Dis. 8 (9), 881-890.

10. Freeman, D.J.; Falkiner, F.R.; Keane, C.T. (1989). New method for detecting slime production by coagulase negative staphylococci. $J$. Clin. Pathol. 42 (8), 872-874.

11. Gaylarde, C.C.; Beech, I.B. (1989). Adhesion of Desulfovibrio desulfuricans and Pseudomonas fluorescens to mild steel surfaces. J. Appl. Microbiol. 67 (2), 201-207.

12. Hood, M.A.; Winter, P.A. (1997). Attachment of Vibrio cholerae under various environmental conditions and to selected substrates. FEMS. Microbiol. Ecol. 22 (3) 215-223.

13. Karunasagar, I.; Otta, S.K. (1996). Biofilm formation by Vibrio harveyi on surfaces. Aquaculture. 140 (3), 241-245.
14. Kogure, K.; Ikemoto, E.; Morisaki, H. (1998). Attachment of Vibrio alginolyticus to glass surfaces is dependent on swimming speed. $J$. Bacteriol. 180 (2), 932-937.

15. Lopez-Cortes, L.; Luque, A.; Martinez-Manzanares, E.; Castro, D.; Borrego, J.J. (1999). Adhesion of Vibrio tapetis to clam cells. J. Shellfish. Res. 18 (1), 91-97.

16. Mack, D.; Rohde, H.; Dobinsky, S.; Riedewald, J.; Nedelmann, M.; Knobloch, J.K.; Elsner, H.A.; Feucht, H.H. (2000). Identification of three essential regulatory gene loci governing expression of the Staphylococcus epidermidis polysaccharide intercellular adhesin and biofilm formation. Infect. Immun. 68 (7), 3799-807.

17. Marshall, K.C.; Stout, R.; Mitchell, R. (1971). Mechanism of the initial events in the sorption of marine bacteria to surfaces. J. Gen. Microbiol. 68, 337-348.

18. Miliotis, M.D.; Tall, B.D.; Gray, R.T. (1995). Adherence to and invasion of tissue culture cells by Vibrio hollisae. Infect. Immun. 63 (12), 4959-4963.

19. Muller, E.; Hübner, J.; Gutierrez, N.; Takeda, S.; Goldmann, D. A.; Pier, G. B. (1993). Isolation and characterisation of transposon mutants of Staphylococcus epidermidis deficient in capsular polysaccharide/ adhesion and slime. Infect. Immun. 61 (2), 551558.

20. Ophir, T.; Gutnick, D.L. (1994). A role for exopolysaccharides in the protection of microorganisms from desiccation. Appl. Environ. Microbiol. 60 (2), 740-745.

21. Paranjpye, R.N.; Strom, M.S. (2005). A Vibrio vulnificus type IV pilin contributes to biofilm formation, adherence to epithelial cells, and virulence. Infect. Immun. 73 (3), 1411-1422.

22. Pringent-Combaret, C.; Prensier, G.; Le Thi, T.T.; Vidal, O.; Lejeune, P.; Dorel, C. (2000). Development pathway for biofilm formation in curli-producing Escherichia coli strains: role of flagella, curli and colanic acid. Environ. Microbiol. 2 (6), 450-464.

23. Sechi, L.A.; Deriu, A.; Falchi, M.P.; Fadda, G.; Zanetti, S. (2002). Distribution of virulence genes in Aeromonas spp. Isolated from Sardinian waters and from patients with diarrhoea. J. Appl. Microbiol. 92 (2), 221-227.

24. Stoodley, P.; Sauer, K.; Davies, D.G.; Costerton, J.W. (2002). Biofilms as complex differentiated communities. Аnnu. Rev. Microbiol. 56, 187-209.

25. Subashkumar, R.; Thayumanavan, T.; Vivekanandhan, G.; Perumalsamy, L. (2006). Occurrence of Aeromonas hydrophila in acute gasteroenteritis among children. Indian. J. Med. Res. 123 (1), 61-66.

26. Van Houdt, R.; Aertsen, A.; Jansen, A.; Quintana, A.L.; Michiels, C.W. (2004). Biofilm formation and cell-to-cell signalling in Gramnegative bacteria isolated from a food processing environment. $J$. Appl. Microbiol. 96 (1), 177-184.

27. Van Loosdrecht, M.C.M.; Lyklema, V.J.; Norde, W.; Schraa, G.; Zehnder, A.J.B. (1987). The role of bacterial cell wall hydrophobicity in adhesion. Appl. Environ. Microbiol. 53 (8), 1893-1897.

28. Wolfe, A.J.; Millikan, D.S.; Campbell, J.M.; Visick, K.L. (2004). Vibrio fischeri $o^{54}$ controls motility, biofilm formation, luminescence, and colonization. Appl. Environ. Microbiol. 70 (4), 2520-252.

29. Wong, H.C.; Chung, Y.C.; Yu, J.A. (2002). Attachment and inactivation of Vibrio parahaemolyticus on stainless steel and glass surface. Food. Microbiol. 19 (4), 341-350.

30. Yamamoto, T.; Yokota, T. (1989). Adherence targets of Vibrio parahaemolyticus in human small intestines. Infect. Immun. 57 (8), 2410-2419.

31. Yurdusev, N. (2001). In vitro model for the study of Listeria and Salmonella adherence to intestinal epithelial cells. Turk. J. Biol. 25, 25-35. 